\title{
Chemical Composition and Antioxidant Potential of Pistacia lentiscus L. Essential Oil from Oran (Algeria)
}

\author{
Hamiani Abdelkader, Kambouche Nadia, Bellahouel Salima \\ Organic Synthesis Laboratory, Chemistry Department, Faculty of Exact Sciences and Applied, Oran 1 Ahmed Benbella University, Oran, \\ Algeria \\ Email:kambouche@yahoo.fr, hamianiaek@gmail.com, salimabellahouel@yahoo.fr
}

How to cite this paper: Abdelkader, H., Nadia, K. and Salima, B. (2016) Chemical Composition and Antioxidant Potential of Pistacia lentiscus L. Essential Oil from Oran (Algeria). Advances in Bioscience and Biotechnology, 7, 539-544.

http://dx.doi.org/10.4236/abb.2016.712048

Received: October 29, 2016

Accepted: December 4, 2016

Published: December 7, 2016

Copyright $\odot 2016$ by authors and Scientific Research Publishing Inc. This work is licensed under the Creative Commons Attribution International License (CC BY 4.0).

http://creativecommons.org/licenses/by/4.0/

\section{Abstract}

Essential oil from the leaves of Pistacia lentiscus L. growing in the Oran region in the west of Algeria was obtained by hydrodistillation with a $1.26 \%$ yield on a dry weight basis. Spectrophotometric analyses were employed to highlight the scavenger capacity of this oil using the 2,2-diphenyl-1-picrylhydrazyl (DPPH) test. Twenty compounds were identified by GC and CG/MS analyses, and the main part of the compounds of the oil was terpinene-4-ol (41.24\%) and $\alpha$-terpineol (7.31\%), $\alpha$-pinene (9.48\%), limonene (09.11\%), $\beta$-myrcene (10.5\%), p-cymene (8.67\%) and $\alpha$-phellandrene $(2.20 \%), \beta$-caryophyllene $(12.62 \%)$ as major compounds. The DPPH test shows that Pistacia lentiscus essential oil possesses antiradical activity. A linear correlation (correlation coefficient $R^{2}=0.995, P<0.001$ ) was found between the reduction of DPPH stable free radical and the concentration of Pistacia lentiscus essential oil.

\section{Keywords}

Pistacia lentiscus, Terpinene-4-ol, Essential Oil, Antioxidant Activity

\section{Introduction}

Pistacia lentiscus $\mathrm{L}$. is an aromatic member of the Anacardiaceae family. In Algeria, $P$. lentiscus $\mathrm{L}$. occurs in various regions, the aerial parts of $P$. lentiscus $\mathrm{L}$. has traditionally been used against several diseases [1]. Mastic gum from Pistacia has been used by folkloric medicine for the relief of upper abdominal discomfort, stomachaches, dyspepsia and peptic ulcer [2].

Several biological activities have been attributed to the essential oil from aerial parts of P. lentiscus L. such as their antifungal, antibacterial an antimicrobial effect [3] [4] [5]. 
Some works reported the chemical composition of the essential oil from aerial parts of $P$. lentiscus L. of diverse countries of the Mediterranean region [6]-[20]. The chemical composition of the essential oil derived from the aerial parts is not clear; it is greatly influenced by both geographical origin and isolation technique.

The aim of this work was to evaluate antioxidant activities of the essential oil from aerial parts of $P$. lentiscus $\mathrm{L}$ from the region of Oran (Algeria), in relation with the composition of their compounds.

\section{Materials and Methods}

\subsection{Plant Material}

Leaves of Pistacia lentiscus of the region of Oran were collected in June 2015, during the period of full flowering. Voucher specimens were identified and deposited in the herbarium of the Agricultural Institute in Algeries, Algeria.

\subsection{Isolation of the Essential Oil}

The air-dried plant material ( $80 \mathrm{~g})$, both leaves and flowers, was hydrodistilled in an allglass apparatus according to the method recommended by the European Pharmacopoeia [21]. The essential oil obtained was dried over anhydrous sodium sulfate. Yield based on dry weight of the sample was $1.26 \%$.

\subsection{GC}

Analytical GC was carried out on a Varian (Palo Alto, CA) model 3300 gas chromatograph fitted with a fused silica MFE1 capillary column $(50 \mathrm{~m} \times 0.25 \mathrm{~mm}$, film thickness $0.25 \mu \mathrm{m}$ ), with $\mathrm{N}_{2}$ as the carrier gas at a flow rate of $1.5 \mathrm{~mL} /$ minute, in split mode, with the temperature programmed to rise from $95^{\circ} \mathrm{C}$ to $240^{\circ} \mathrm{C}$ at $4^{\circ} \mathrm{C} /$ minute. The injector temperature was $250^{\circ} \mathrm{C}$, the detector used was a flame ionization detector, and the detector temperature was $300^{\circ} \mathrm{C}$. Injection volume for all samples was $0.1 \mu$.

\subsection{GC/MS}

Analyses were carried out on an Agilent (Palo Alto) 6890 gas chromatograph fitted with a fused Agilent 19091S-433 HP-5MS column $(30.0 \mathrm{~m} \times 0.25 \mathrm{~mm}$; film thickness 0.30 $\mu \mathrm{m}$; temperature programmed from $40^{\circ} \mathrm{C}$ to $280^{\circ} \mathrm{C}$ at $4{ }^{\circ} \mathrm{C} /$ minute) with $\mathrm{He}$ as the carrier gas at a flow rate of $1 \mathrm{ml} /$ minute. The chromatograph was coupled to an HP $5973 \mathrm{~A}$ mass spectrometer (Hewlett Packard, Palo Alto).

\subsection{Identification of Components}

Most constituents were identified by means of GC/MS. Some components were tentatively identified by comparing their retention indices on both chromatographic columns with those of authentic compounds and with literature data [22] [23].

\subsection{Antioxidant Test Free Radical Scavenging Activity (DPPH) Method}

The antioxidant activity was measured by a modification of the DPPH radical scaveng- 
ing method of Ramos et al. [24] Two hundred microliters of distilled water was mixed with $160 \mu \mathrm{L}$ of DPPH $(0.5 \mathrm{mM}$ in ethanol), and then $40-\mathrm{L}$ samples of the oil in ethanol (ranging from 2.50 to $20 \mu \mathrm{L} / \mathrm{mL}$ ) were added. The mixture was shaken and left to stand at room temperature. The absorbance $(A)$ was measured 30 minutes later at $517 \mathrm{~nm}$.

The inhibition potential (IP) (as a percentage) is measured using the formula:

$$
\mathrm{IP}=\left(\mathrm{A}_{\mathrm{DPPH}}-\mathrm{A}_{\text {sample }} / \mathrm{A}_{\mathrm{DPPH}}\right) \text {. }
$$

\subsection{Statistical Analysis}

All evaluations of antioxidant activity were performed twice. The experimental data were expressed as means \pm standard deviation (S.D). The correlation coefficient of antioxidant activity was determined using Excel programme and Origin 6.

\section{Results}

Hydrodistillation of dried leaves of $P$. lentiscus yielded $1.26 \%$. Twenty compounds, representing $97.63 \%$ of the oil, were identified. Results of the qualitative determination of the different constituents, together with those of the quantitative analysis are compiled in Table 1 . The main compounds were oxygenated monoterpenes, characterized by the great prevalence of terpinene-4-ol (41.24\%) and $\alpha$-terpineol (7.31\%), $\alpha$-pinene (9.48\%), limonene (09.11\%), $\beta$-myrcene (10.5\%), p-cymene (8.67\%) and $\alpha$-phel-landrene $(2.20 \%), \beta$-caryophyllene (22.62\%) as major compounds.

As shown in Figure 1, the P. lentiscus essential oil reduced the stable free radical DPPH in a concentration-dependent manner. The relationship between the antiradical activity and the concentration of Pistacia lentiscus essential oil (Figure 1) was positive and significant $\left(R^{2}=0.995, P<0.001\right)$.

The extract concentration producing $50 \%$ inhibition was calculated (Figure 1); it represents $0.39 \mathrm{mg} / \mathrm{ml}$, corresponding to $0.05 \mathrm{mg} / \mathrm{mL}$ ascorbic acid (data not shown).

\section{Discussion}

These results show that Pistacia lentiscus is rich in oxygenated monoterpene.

To the best of our knowledge this work is therefore the first report on the essential oil of Pistacia lentiscus from Oran Algeria.

In other countries of the Mediterranean region, several studies have been studied the chemical composition of P. lentiscus L. oil [6]-[20] and several compositions were observed. Myrcene (39.2\%), which is the major compounds of our essential oil, has also the abundant compound in the samples from Morocco (38\%) [4], France (76.9\%) [6], Spain (27\%) [7], Italy (25.2\%) [8] and Algeria (23.0\% - 33.1\%) [9].

On the other hand, $\alpha$-pinene was the major compound of the essential oils from Morocco (16.1\% - 38.5\%) [10], Algeria (20.0\% - 34.2\% and 19\%) [9] [19], Tunisia (16.8\%) [11], Greece (24.9\% - 9.4\%) [12], Italy (14.8\% - 22.6\% and 18\%) [13] [14], Spain (13.0\%) [15] and France (31.9\%) [6].

In our study terpinene-4-ol was by far the major component (41.24\%) accompanied 
Table 1. Percentage of essential oil composition of P. lentiscus.

\begin{tabular}{|c|c|c|c|}
\hline Peak number & Compound & Kovats index & Percentage (\%) \\
\hline 1 & $\alpha$-pinene & 928 & 9.48 \\
\hline 2 & $\beta$-Myrcene & 948 & 0.9 \\
\hline 3 & $\alpha$-phellandrene & 964 & 2.20 \\
\hline 4 & $\beta$-pinene & 966 & $\mathrm{t}$ \\
\hline 5 & Cis-ocimene & 976 & $\mathrm{t}$ \\
\hline 6 & Unknow & 998 & - \\
\hline 7 & 3-carene & 1005 & 0.8 \\
\hline 8 & $\delta$-Carene & 1012 & $\mathrm{t}$ \\
\hline 8 & Limonene & 1018 & 09.11 \\
\hline 9 & p-Cymene & 1028 & 8.67 \\
\hline 10 & p-cymen-8-ol & 1042 & $\mathrm{t}$ \\
\hline 11 & Terpinolene & 1052 & $\mathrm{t}$ \\
\hline 12 & Linalool & 1082 & 1.4 \\
\hline 13 & Verbenol & 1122 & 0.7 \\
\hline 14 & Terpinene-4-ol & 1137 & 41.24 \\
\hline 15 & Borneol & 1138 & 0.8 \\
\hline 16 & $\alpha$-terpineol & 1174 & 7.31 \\
\hline 17 & 2-Undecanone & 1290 & 0.7 \\
\hline 18 & Isoledene & 1419 & 0.9 \\
\hline 19 & Unknow & 1458 & - \\
\hline 20 & $\beta$-caryophyllene & 1494 & 12.62 \\
\hline 22 & Globulol & 1530 & 0.8 \\
\hline
\end{tabular}

Components are arranged in order of MFE1 elution, t: trace percentage $(\%) \leq 0.6$.

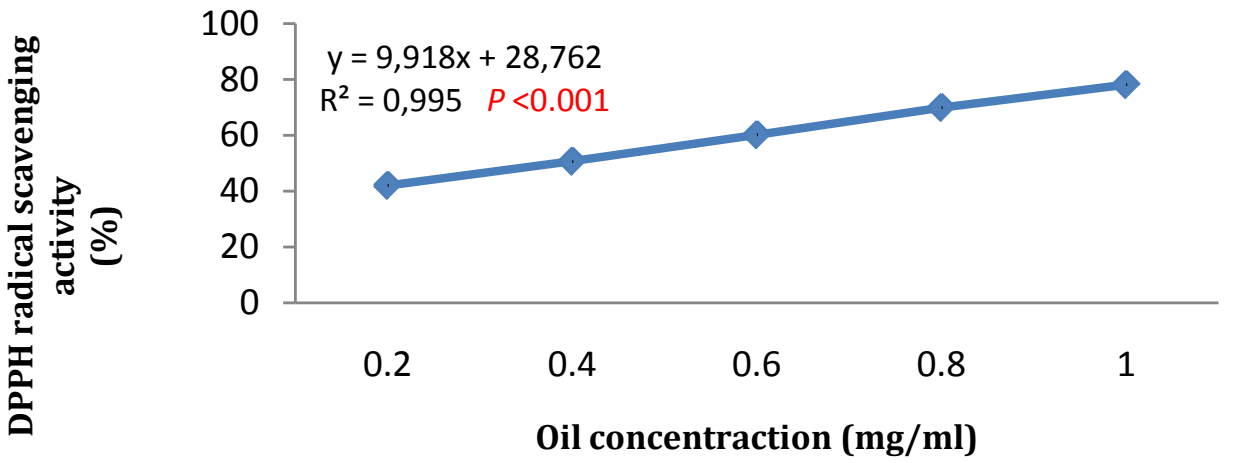

Figure 1. Positive correlation between the reduction of DPPH stable radical and the concentration of Pistacia lentiscus essential oil. 
by limonene $(09.11 \%), \beta$-myrcene $(10.5 \%)$ and $\beta$-caryophyllene $(12.62 \%)$. it is worth noting that this oil is the richest source of naturally occurring terpinene-4-o that has been found.

Besides, terpinen-4-ol was mainly present in the oils from Morocco (14.5\% - 19.3\%) [10], Algeria (17.3\% - 34.7\%) [16], Turkey (30.0\% and 29.2\%) [17] [18], and France (25.6\%) [6]. Other chemotypes were also reported: longifolene (16.4\% - 12.8\% Algeria) [19] limonene (47.0\% France and 44\% - 29\% Algeria) [6] [9]; $\beta$-caryophellene (19.3\% 13.1\% Algeria [9] and 31.5\% Italy [20].

The antioxidant activity of Pistacia lentiscus essential oil may provide a protective effect from oxidative stress-related diseases.

As a result, the antioxidant activity of the essential oil was generally ascribed to the terpenes.

\section{Conclusion}

In conclusion, essential oil from Pistacia lentiscus and its components generally displayed strong antioxidant properties, which are useful in daily life in foods and as preventive agents against various diseases.

\section{References}

[1] Bentley, R.Y. and Trimen, H. (1980) Medicinal Plants. J. and A Churchill, London, 68.

[2] Al-Habbal, M.J., Al-Habbal, Z. and Huwez, F.U. (1984) A Double-Blind Controlled Clinical Trial of Mastic and Placebo in the Treatment of Duodenal Ulcer. Clinical and Experimental Pharmacology and Physiology, 11, 541-544. https://doi.org/10.1111/j.1440-1681.1984.tb00864.x

[3] Barra, A., Coroneo, V., Dessi, S., Cabras, P. and Angioni, A. (2007) Characterization of the Volatile Constituents in the Essential oil of Pistacia lentiscus L. from Different Origins and Its Antifungal and Antioxidant Activity. Journal of Agricultural and Food Chemistry, 55, 7093-7098. https://doi.org/10.1021/jf071129w

[4] Lamiri, A., Lahloui, S., Benjilali, B. and Berrada, M. (2001) Insecticidal Effects of Essential Oils against Hessian Fly, Mayetiola destructor (Say). Field Crops Research, 71, 9-15. https://doi.org/10.1016/S0378-4290(01)00139-3

[5] Bonsignore, L., Cottiglia, F. and Loy, G. (1998) Antimicrobial Activity of Pistacia lentiscus Aerial Part. Fitoterapia, 69, 537-538.

[6] Castola, V., Bighelli, A. and Casanova, J. (2000) Intraspecic Chemical Variability of the Essential Oil of Pistacia lentiscus L. from Corsica. Biochemical Systematics and Ecology, 28, 79-88. https://doi.org/10.1016/S0305-1978(99)00038-1

[7] Boelens, M.H. and Jimenez, R. (1991) Chemical Composition of the Essential Oil from the Gum and Various Parts of Pistacia lentiscus L. (Mastic Gum Tree). Flavour and Fragrance Journal, 6, 271-275. https://doi.org/10.1002/ffj.2730060406

[8] Calabro, G. and Curro, P. (1974) Costituenti degli oli essenziali Nota IV. Essenza di lentisco. Essenz Derive. Agrumes, 44, 82-92.

[9] Mecherara-Idjeri, S., Hassani, A., Castola, V. and Casanova, J. (2008) Composition and Chemical Variability of the Essential Oil from Pistacia lentiscus L. Growing Wild in Algeria Part 1: Leaf Oil. Journal of Essential Oil Research, 20, 32-38.

[10] Zrira, S., Elamrani, A. and Benjilali, B. (2003) Chemical Composition of the Essential Oil of 
Pistacia lentiscus L. from Morocco-A Seasonal Variation. Flavour and Fragrance Journal, 18, 475-480. https://doi.org/10.1002/ffj.1221

[11] Ben Douissa, F., Hayder, N., Chekir-Ghedira, L., Hammami, M., Ghedira, K. and Mariotte Dijoux-Franca, A.-M. (2005) New Study of the Essential Oil from Leaves of Pistacia lentiscus L. (Anacardiaceae) from Tunisia. Flavour and Fragrance Journal, 20, 410-414.

https://doi.org/10.1002/ffj.1445

[12] Chryssavgi, G., Vassiliki, P., Athanasios, M., Kibouris, Th. and Michael, K. (2008) Essential Oil Composition of Pistacia lentiscus L. and Myrtus communis L.: Evaluation of Antioxidant Capacity of Methanolic Extracts. Food Chemistry, 107, 1120-1130. https://doi.org/10.1016/j.foodchem.2007.09.036

[13] Barra, A., Coroneo, V., Dessi, S., Cabras, P. and Angioni, A. (2007) Characterization of the Volatile Constituents in the Essential Oil of Pistacia lentiscus L. from Different Origins and Its Antifungal and Antioxidant Activity. Journal of Agricultural and Food Chemistry, 55, 7093-7098. https://doi.org/10.1021/jf071129w

[14] Lo Presti, M., Sciarrone, D., Crupi, M. L., Rosaria, C., Salvatore, R., Giovanni, D. and Luigi, M. (2008) Evaluation of the Volatile and Chiral Composition in Pistacia lentiscus L. Essential Oil. Flavour and Fragrance Journal, 20, 32-38.

[15] Fernandez, A., Camacho, A., Fernandez, C., Perez, P. and Altarejos, J. (2000) Composition of the Essential Oils from Galls and Aerial Parts of Pistacia lentiscus L. Journal of Essential Oil Research, 12, 19-23. https://doi.org/10.1080/10412905.2000.9712031

[16] Benyoussef, E.H., Charchari, S., Nacer-Bey, N., Yahiaoui N., Chakou, A. and Bellatreche, M. (2005) The Essential Oil of Pistacia lentiscus L. from Algeria. Journal of Essential Oil Research, 17, 642-644. https://doi.org/10.1080/10412905.2005.9699021

[17] Duru, M.E., Cakir, A., Kordali S., Zengin H., Harmandar, M., Izumi, S. and Hirata, T. (2003) Chemical Composition and Antifungal Properties of Essential Oils of Three Pistacia Species Grown in Turkey. Fitoterapia, 74, 170-176. https://doi.org/10.1016/S0367-326X(02)00318-0

[18] Kivçak, B., Akay S., Demirci, B. and Baser, K.H.C. (2004) Chemical Composition of Essential Oils from Leaves and Twigs of Pistacia lentiscus, Pistacia lentiscus var. chia and Pistacia terebinthus from Turkey. Pharmaceutical Biology, 42, 360-366. https://doi.org/10.1080/13880200490519677

[19] Dob, T., Dahmane, D. and Chelghoum, C. (2006) Chemical Composition of the Essential Oils of Pistacia lentiscus L. from Algeria. Journal of Essential Oil Research, 18, 335-338. https://doi.org/10.1080/10412905.2006.9699105

[20] Congiu, R., Falconieri, D., Marongiu B., Piras, A. and Porcedda, S. (2002) Extraction and Isolation of Pistacia lentiscus L. Essential Oil by Supercritical $\mathrm{CO}_{2}$. Flavour and Fragrance Journal, 17, 239-244. https://doi.org/10.1002/ffj.1095

[21] (2004) European Pharmacopoeia. Vol. 2, 5th Edition, Council of Europe, Strasbourg, France.

[22] Ennings, W. and Shibamoto, T. (1980) Qualitative Analysis of Flavor and Fragance Volatiles by Capillary Gas Chromatography. Academic Press, New York.

[23] Adams, R.P. (2001) Identification of Essential Oil by Gas Chromatography/Quadrupole Mass Spectrometry. Allured, Carol Stream, IL.

[24] Ramos, A., Visozo, A., Piloto, J., Garcia, A. and Rodriguez, C.A. (2003) Screening of Antimutagenicity via Antioxidant Activity in Cuba Medicinal Plants. Journal of Ethnopharmacology, 87, 241-246. https://doi.org/10.1016/S0378-8741(03)00156-9 
Submit or recommend next manuscript to SCIRP and we will provide best service for you:

Accepting pre-submission inquiries through Email, Facebook, LinkedIn, Twitter, etc. A wide selection of journals (inclusive of 9 subjects, more than 200 journals)

Providing 24-hour high-quality service

User-friendly online submission system

Fair and swift peer-review system

Efficient typesetting and proofreading procedure

Display of the result of downloads and visits, as well as the number of cited articles

Maximum dissemination of your research work

Submit your manuscript at: http://papersubmission.scirp.org/

Or contact abb@scirp.org 